\title{
DC Electrical Conductivity of Cellulose
}

\author{
Masae TAKAHASHI and Haruko TAKENAKA \\ Faculty of Home Economics, Japan Women's University, \\ 2-8-1 Mejirodai, Bunkyo-ku, Tokyo 112, Japan
}

(Received February 12, 1983)

\begin{abstract}
DC electrical conductivity was measured from room temperature to about $230^{\circ} \mathrm{C}$ for Cellulose I and Cellulose II. The conductivity $v$ s. temperature curve showed a break at about $150^{\circ} \mathrm{C}$ for Cell I and at about $80^{\circ} \mathrm{C}$ for Cell II. The break points corresponded to those observed previously in the spacing $v s$. temperature curves. These phenomena may possibly be associated with the second order transition at which the restricted motion of chain segments in the crystals begins to acquire high mobility. The conductivity in the fiber axis direction was approximately ten times as large as that in the perpendicular direction.

KEY WORDS Cellulose I / Cellulose II / Transition Point / DC Electrical Conductivity /
\end{abstract}

In a previous paper, ${ }^{1}$ it was found for Cell I (Cellulose I) and Cell II (Cellulose II) that the temperature coefficients of the spacings and intensities of X-ray reflections change discontinuously at $150^{\circ} \mathrm{C}$ for Cell I and at $100^{\circ} \mathrm{C}$ for Cell II. This suggests that these crystals undergo second order transitions at these temperatures. The present work was undertaken to confirm this, by measuring the dc electrical conductivity from room temperature to about $230^{\circ} \mathrm{C}$ for both Cell I and Cell II. Furthermore, the anisotropy of the dc electrical conductivity was studied in the directions of intermolecular and intramolecular hydrogen (chain direction) bonds to observe the effects of hydrogen bonds on the electrical conductivity.

\section{EXPERIMENTAL}

The samples of Cell I were prepared from softwood tsuga (Tsuga sieboldii CARR) and hardwood kaba (Betula tauschii KoIDz), both of which showed clear X-ray meridional reflections. The crystallinities of the untreated samples were almost the same. The samples of Cell II were prepared by measerizing tsuga and kaba with $30 \% \mathrm{NaOH}$ for $240 \mathrm{~h}$ followed by regeneration by washing with cold water. The degree of transformation from Cell I into Cell II was 0.9-1.0, when estimated by Ranby's equation. ${ }^{2}$ All the samples were treated with $4 \mathrm{~N}-\mathrm{HCl}$ at $100^{\circ} \mathrm{C}$ for $2-10 \mathrm{~h}$ to remove any lignin and hemicellulose in the wood.

The sample was parallelpiped in form $(10 \mathrm{~mm} \times 10 \mathrm{~mm} \times 15 \mathrm{~mm})$. The arrangement of electrodes and the direction of electric current is illustrated in Figure 1. Stainless steel was used as the electrodes. Silver conducting paste (du Pont Electro-Chemicals Department No. 5504) was spread on both sides of the sample and heated at $200^{\circ} \mathrm{C}$ for $70 \mathrm{~min}$ in order to insure closer contact between the stainless steel and wood.

DC electrical conductivity was measured with the dc amplifier shown in Figure 2. The maximum applied voltage was $300 \mathrm{~V}$ and the standard resistance, $1 \mathrm{k} \Omega$. Prior to each measurement, the specimen was dried at $100^{\circ} \mathrm{C}$ for about $2 \mathrm{~h}$ under a pressure of $10^{-3}$ torr.

\section{RESULTS AND DISCUSSION}

The temperature dependence of the dc electrical conductivity $\sigma$ of Cell I (tsuga) hydrolyzed with $4 \mathrm{~N}$ $\mathrm{HCl}$ at $100^{\circ} \mathrm{C}$ for various hours is shown in Figure 3. Figure $3 \mathrm{~A}$ is for the fiber direction and Figure 3B, for the direction perpendicular to it. Breaks are seen at temperatures of about $150^{\circ} \mathrm{C}$ in both directions, and the temperature of the break point decreases slightly as the hydrolysis reaction proceeds. Figure 4 shows the relationship between electrical conduc- 




(1)

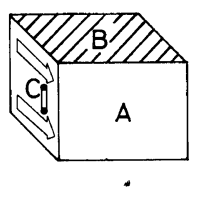

(2)
Figure 1. Arrangement of electrodes for measurement of conductivity in the (1) fiber direction and (2) tangential direction: A, cross face; $\mathrm{B}$, radial face; $\mathrm{C}$, tangential face; $\mathbb{Z}$, electrode; $\Longrightarrow$, fiber axis; $\rightleftharpoons$, intramolecular hydrogen bond; $\longrightarrow$, intermolecular hydrogen bond.

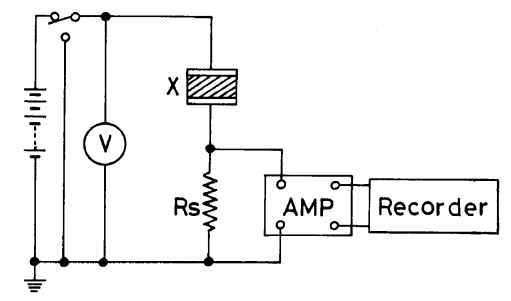

Figure 2. Schematic diagram of the apparatus for measuring time-dependent conductivity in a d.c. field: V, voltmeter; X, sample; Rs, standard resistance. tivity and temperature for Cell I (tsuga) and Cell II (tsuga), each hydrolyzed with $4 \mathrm{~N}-\mathrm{HCl}$ at $100^{\circ} \mathrm{C}$ for $6 \mathrm{~h}$. The break point for Cell II is located in the vicinity of $80^{\circ} \mathrm{C}$.

The break points found here correspond to those previously observed in the crystal spacing $v s$. temperature curves. ${ }^{1}$ The apparent activation energy $\Delta H^{*}$ was estimated from Figures 3 and 4 , with the results shown in Table I. The activation energy $\Delta H^{*}$ of Cell $\mathrm{I}$ is constant for samples hydrolyzed for more than $2 \mathrm{~h}$. Cell II gives similar values for $\Delta H^{*}$. The dissociation energies can be calculated by substituting these activation energies into Murphy's equation, ${ }^{3}$ i.e.,

$$
\begin{aligned}
\sigma=\sigma_{01} \exp [- & \left.\left(\frac{1}{2} W_{\mathrm{d}}+W_{\mathrm{a}}\right) / R T\right] \\
& +\sigma_{02} \exp \left(-W_{\mathrm{a}} / R T\right)
\end{aligned}
$$

where $W_{\mathrm{d}}$ is the energy for dissociation into ion pairs and $W_{\mathrm{a}}$ is the activation energy for the mobility of these ions. The calculated dissociation energies of $1.2-1.4 \mathrm{eV}$ are smaller than $1.72 \mathrm{eV}$ estimated for the activation energy for thermal decomposition. ${ }^{3,4}$ Therefore, it is unlikely that the marked increase in dc conductivity above the break
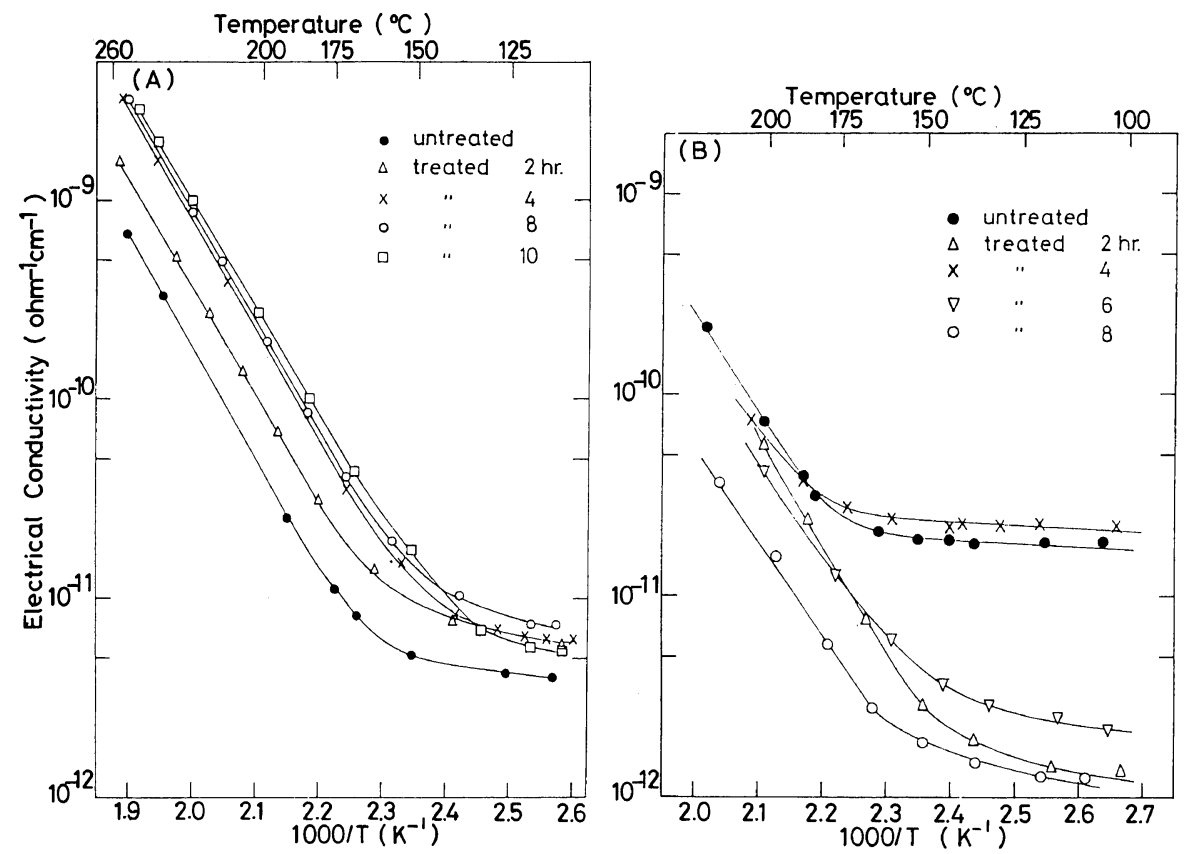

Figure 3. Temperature dependence of the d.c. conductivity for Cell I (tsuga) hydrolyzed with $4 \mathrm{~N}-\mathrm{HCl}$ at $100^{\circ} \mathrm{C}$ for indicated hours: A, fiber direction; B, tangential direction. 


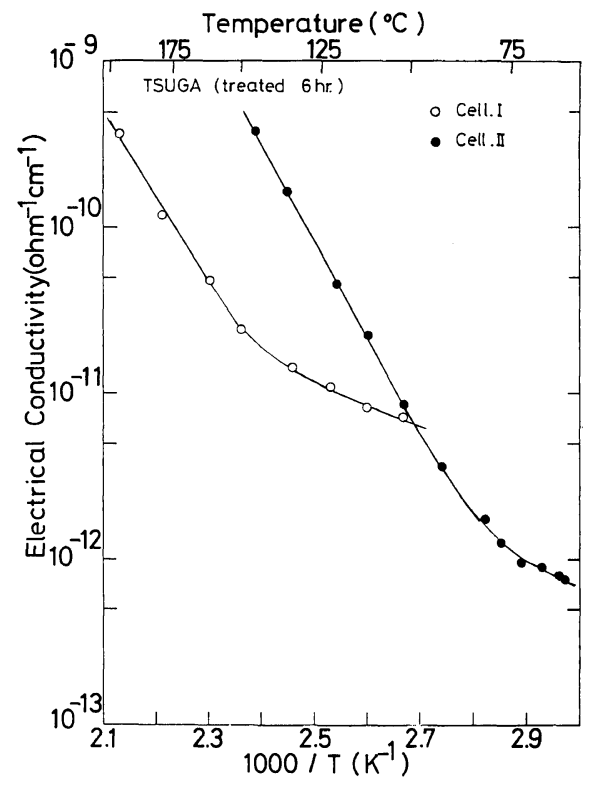

Figure 4. Temperature dependence of the d.c. conductivity for Cell I and Cell II in the fiber direction.

Table I. Values of apparent activation energy $\Delta H^{*}$ of Cell I

\begin{tabular}{|c|c|c|c|c|}
\hline \multirow{2}{*}{ Sample } & \multicolumn{2}{|c|}{$\begin{array}{c}\Delta H^{*} / \mathrm{eV} \\
\text { (above break point) }\end{array}$} & \multicolumn{2}{|c|}{$\begin{array}{c}\Delta H^{*} / \mathrm{eV} \\
\text { (below break point) }\end{array}$} \\
\hline & $\|^{\mathbf{a}}$ & $\perp^{b}$ & $\|$ & $\perp$ \\
\hline Tsuga & 1.1 & 1.0 & 0.5 & 0.3 \\
\hline Kaba & 1.2 & 1.0 & 0.4 & 0.3 \\
\hline
\end{tabular}

a Fiber direction.

b Perpendicular direction.

point is due to an increase in the number of charge carriers caused by decomposition.

It has been found ${ }^{5,6}$ that the temperature coefficient of the electrical conductivity of polymers increases suddenly at the glass transition temperature $T_{\mathrm{g}}$. This phenomenon can be interpreted qualitatively as resulting from a remarkable increase in the mobility of the current carriers due to activated segmental motion of the amorphous chains. In our case, however, the break points of 150 and $80^{\circ} \mathrm{C}$ were far below the $T_{\mathrm{g}}$ of cellulose $\left(>240^{\circ} \mathrm{C}\right)$. $^{7,8} \mathrm{It}$ has been proposed ${ }^{9}$ that cellulose has another second order transition at about $113^{\circ} \mathrm{C}$ and this may be attributed to enhanced thermal motion caused by

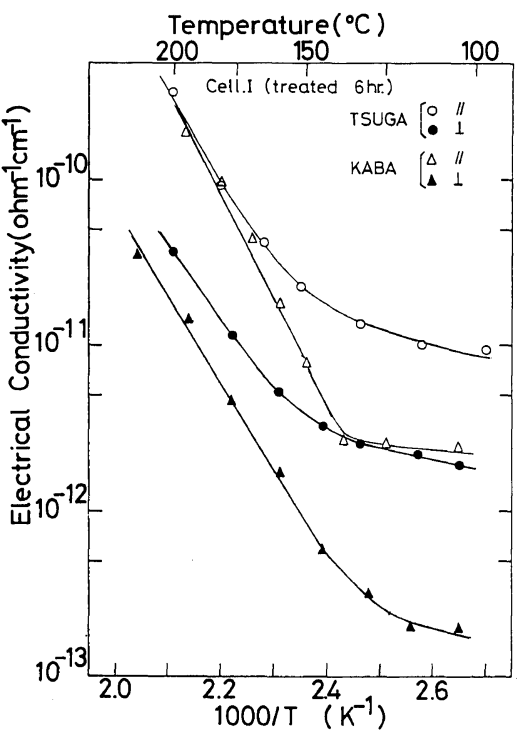

Figure 5. Temperature dependence of the d.c. conductivity for tsuga (Cell I) and kaba (Cell I) in two directions; //, fiber direction; $\perp$, tangential direction.

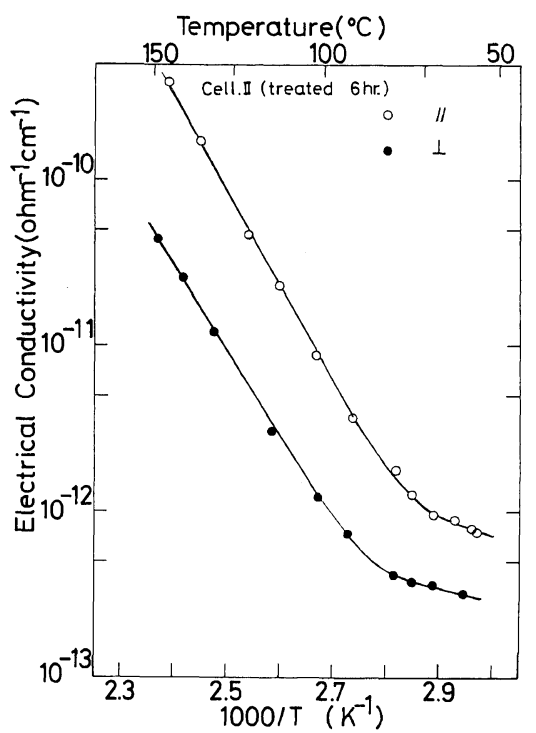

Figure 6. Temperature dependence of the d.c. conductivity for Cell II (tsuga) in two directions; //, fiber direction; $\perp$, tangential direction.

the breaking of weak hydrogen bonds. Therefore, the break points observed in the electrical conductivity curves may be considered as reflecting the second order transition of the crystal. It should be 

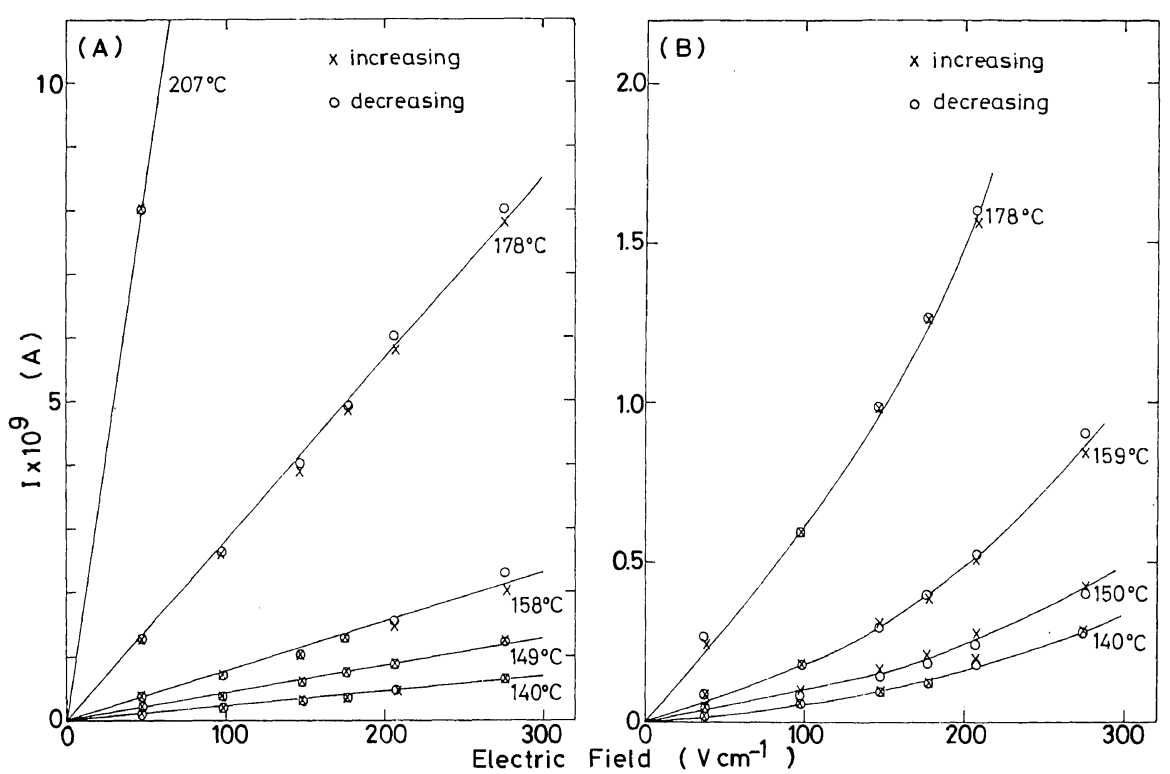

Figure 7. Voltage-current characteristics in Cell I (tsuga) in two directions: A, fiber direction; B, tangential direction.

noted that the transition point $T_{\mathrm{r}}$ for Cell II $\left(80^{\circ} \mathrm{C}\right)$ is much lower than that for Cell $\mathrm{I}\left(150^{\circ} \mathrm{C}\right)$. The difference may be due to the greater flexibility of the Cell II chain. Therefore, the marked increase in electrical conductivity above $T_{\mathrm{r}}$ may be attributed mainly to an increase in the mobility of the current carriers.

Our interest was directed to the anisotropic dc electrical conductivities in the directions of intramolecular (fiber direction) and intermolecular hydrogen bonds (perpendicular direction). Figure 5 shows the values of $\sigma$ in these two directions plotted against $1 / T$ for Cell I (tsuga and kaba) treated with $4 \mathrm{~N}-\mathrm{HCl}$ at $100^{\circ} \mathrm{C}$ for $6 \mathrm{~h}$. The conductivity in the fiber direction is approximately ten times as large as that in the perpendicular direction. A similar result was obtained from the temperature dependence of $\sigma$ for Cell II shown in Figure 6.

Figure 7 shows the voltage-current characteristics for these two directions of Cell I (tsuga) at various temperatures. Results similar to those in Figure 7 were obtained for Cell II. The voltage-current curves in the perpendicular direction show a nonlinear relation in contrast to those in the fiber direction. This nonlinear effect may be due to a potential barrier which always exists in poly- mers. ${ }^{10,11}$ Thus, the electric current in the tangential direction is disturbed by the potential barrier more intensely than that in the fiber direction.

\section{CONCLUSION}

The dc electrical conductivity vs. temperature curve shows a break at about $150^{\circ} \mathrm{C}$ for Cell $\mathrm{I}$ and about $80^{\circ} \mathrm{C}$ for Cell II. The break points correspond to those observed in the spacing $v s$. temperature curves, implying that they are related to the second order transition of crystals above which the restricted segmental motion of the chain becomes free. The conductivity in the fiber direction was approximately ten times as large as that in the perpendicular direction.

Acknowledgment. The authors wish to express their appreciation to Dr. P. H. Kim for his valuable comments and guidance.

\section{REFERENCES}

1. M. Takahashi and H. Takenaka, Polym. J., 14, 675 (1982).

2. B. G. Ranby, Acta Chem. Scand., 6, 116 (1952).

3. E. J. Murphy, Can. J. Phys., 41, 1022 (1963). 


\section{Electrical Conductivity of Cellulose}

4. E. J. Murphy, J. Polym. Sci., 58, 649 (1962).

5. S. Saito, H. Sasabe, T. Nakajima, and K. Yoda, $J$. Polym. Sci., A-2, 6, 1297 (1968).

6. H. Sasabe, K. Sawamura, S. Saito, and K. Yoda, Polym. J., 2, 518 (1971).

7. K. Tsuge and Y. Wada, J. Phys. Soc. Jpn., 17, 156 (1962).
8. I. Sakurada, "Seni no Kagaku," Japan, Ed., Sankyo Publishing Co., Tokyo, 1978, p 149.

9. M. V. Ramiah and D. A. I. Goring, J. Polym. Sci., C, 27 (1965).

10. L. E. Amborski, J. Polym. Sci., 62, 331 (1962).

11. S. Hirota, Circulars of The Electrotechnical Laboratory, No. 166, Tokyo, 1969. 